\title{
Thyroid Dysfunction and Abnormal Uterine Bleeding
}

\section{Tara*}

University of Baghdad, Iraq

Submission: June 03, 2019 ; Published: July 01, 2019

*Corresponding author: Tara, University of Baghdad, Iraq

\section{Abstract}

Background: The abnormal uterine bleeding represents the common complaint of women attending clinics. Abnormal thyroid dysfunction in women specifically the hypothyroidism has been related to menstrual disturbances in women at reproductive age.

Objectives: This study aimed to measure the prevalence of thyroid dysfunction in women presented with abnormal uterine bleeding in Erbil city.

Methods: A cross sectional prospective study conducted in the outpatient Clinic at Maternity Teaching Hospital in Erbil city from 1st of September, 2017 to 30th of June, 2018 on 100 women (50 women with abnormal uterine bleeding and 50 women with a normal cycle selected as control cases. The general and menstrual history in addition to investigations and thyroid function test of both study groups were assessed.

Results: There was a significant association between high thyroid stimulating hormone level and women with abnormal uterine bleeding $(\mathrm{p}=0.002)$. Women with abnormal uterine bleeding were significantly associated with low T4 level $(\mathrm{p}=0.04)$. A significant association was observed between women with abnormal uterine bleeding and hypothyroidism $(\mathrm{p}=0.003)$.

Conclusion: The thyroid dysfunction is common cause of abnormal uterine bleeding among women at reproductive age.

Keywords: Abnormal uterine bleeding; Thyroid dysfunction; Reproductive age women

\section{Introduction}

The abnormal uterine bleeding (AUB) is defined as a symptom that represent the frequent complaint of women attending Gynecology clinics. The AUB is affecting women in pre and postmenopausal age periods [1]. Clinically, It presented in many forms like menorrhagia, metrorrhagia, menometrorrhagia, polymenorrhea, polymenorrhagia and oligmenorrhea [2]. New classification system was developed by International Federation of Gynecology and Obstetrics used to categorize the causes of AUB in reproductive age and based on acronym (polyps, adenomyosis, leiomyoma, malignancy and hyperplasia-coagulopathy, ovulatory disorders, iatrogenic, not classified) [3]. The causes of AUB might be related to hormonal balance disturbances or it might be clinical presentation for benign or malignant lesions of female genital tract in reproductive age group woman. The dysfunctional uterine bleeding (DUB) is adopted in the absence of abnormal pathological changes [3]. AUB in most of Iraqi women younger than 60 years age is found to be predominantly dysfunctional in origin. However, it is related to abnormal pathology in others [4].
The thyroid dysfunctions are common all over the world and the thyroid diseases are 10 times more prevalent among women than men [5]. In Iraq, nontoxic goiter presents in about one third of women and the toxic goiter in about $25 \%$ of women while the hypothyroidism is detected in about $14.5 \%$ of women [6]. The thyroid dysfunction in women is related to abnormal menstrual cycle [7]. Thyroid hormones are responsible in initiation of many physiological processes in females like pubertal growth \& development, menarche, menstrual cycles, fertility and menopause [8].

The mechanism by which the thyroid disorders is associated with AUB may be explained by altering thyroid stimulating hormone (TSH) response, increasing prolactin levels, altering luteinizing hormone (LH) response, affecting peripheral conversion of androgens to estrogens, altering sex hormone binding globulin (SHBG) and affecting coagulation pathways in addition to effect on lipid profile [9]. 
The hypothyroidism is a frequent cause of multiple disorders in women at reproductive age ranged from sexual dysfunction, menstrual abnormalities and infertility [10]. Disturbed cycles and abnormal blood flow are the first menstrual problems for women with hypothyroidism $[5,10]$. The occult menorrhagia is an earlier presentation for women with subclinical hypothyroidism [11]. The menstrual irregularity was the presenting symptom of $24 \%$ of Iraqi women diagnosed with hypothyroidism [12].

For hyperthyroidism, it delays the onset of menses if occurs before puberty [5], while in reproductive age group, it is related to oligomenorrhea and amenorrhea [13]. In Erbil, the women have four times risk in developing hyperthyroidism than men [14]. Menstrual disturbances in women with thyroid dysfunction are sometimes the first symptoms which help in diagnosis, however, the subclinical thyroid cases (hyper- and hypothyroidism), might be neglected for many years [5]. There is evolutionary increase in the number of women attending with AUB to medical clinics in our country $[6,4]$. The rationale of this study which aimed to measure the prevalence of thyroid dysfunction in women that presented with abnormal uterine bleeding in Erbil city.

\section{Patients and Methods}

This study is a cross sectional prospective study conducted in the outpatient Clinic at Maternity Teaching Hospital in Erbil city from $1^{\text {st }}$ of September, 2017 to $30^{\text {th }}$ of June, 2018 (10 month).Ethical approval of the study was taken from Ethical Committee of Kurdistan Board of Medical Specialties and administration of the Maternity hospital. Confidentiality was taken in consideration and verbal consent was taken before enrolling women in the study. We recruited all the women that presented with abnormal uterine bleeding (AUB) to the clinic. The inclusion criteria were women in reproductive age group (18-42 years) with clinical presentation of AUB. The exclusion criteria were pregnancy related bleeding, bleeding disorders, use of intrauterine contraceptive device. A convenient sample of 50 women with AUB was selected after eligibility to inclusion and exclusion criteria. Another sample of 50women with normal cycle selected as control cases after verbal consent. The data was collected by researcher through direct interview with the

Table 1: Baseline characteristics of women with AUB $(n=50)$. selected women and completed prepared questionnaire. The questionnaire was designed by the supervisor and researcher. It included the sociodemographic characteristics of the participants (age, occupation and marital status), parity history, body mass index, smoking history, contraception history, drugs history (anti-coagulants and anti-thyroid), LMP frequency, menstrual bleeding patterns, post coital bleeding, intermenstrual bleeding, thyroid stimulating hormon level, triiodothyronine level, thyroxin level. After taking full history and examination, the eligible women were referred to Laboratory and Radiology department of Erbil Maternity Teaching Hospital to complete the investigations. The thyroid function tests were carried out by the Mini Vidas ELFA (enzyme linked fluorescent assay) method and immunoradiometric assay (IRMA). The normal limit values of TSH, T3 and T4 were $0.4-5 \mu \mathrm{U} / \mathrm{ml}, 3.5-6.5 \mathrm{pmol} / \mathrm{L}$ and 8.5-15.2pmol/L, respectively.

All women's data entered using computerized statistical software; Statistical Package for Social Sciences (SPSS) . Descriptive statistics presented as (mean \pm standard deviation) and frequencies as percentages. Multiple contingency tables conducted and appropriate statistical tests performed. In all statistical analysis, level of significance ( $p$ value) set at $\leq 0.05$ and the result presented as tables and/or graphs.

\section{Result}

Total 50 women with AUB were included in this study with mean age of 32.4 years; $12 \%$ were less than 20 years age, $30 \%$ of women were in age group $20-29$ years, $34 \%$ of women were in age group 30-39 years and $24 \%$ of women were 40 years age and more. About two thirds (70\%) of women with AUB were housewives and $82 \%$ of them were married; $17.1 \%$ of those married women with AUB were nulliparous while $82.9 \%$ of them had children. The smoking history was positive for $8 \%$ of women with AUB. The women presented with AUB (26\%) of them were overweight and (42\%) were obese the mean BMI was (27.8 Kg.m².). The history of contraception was observed among $17(34 \%)$ women with AUB, while history of thyroid replacement therapy was observed in two (4\%) women (Table 1).

\begin{tabular}{|c|c|}
\hline Variable & No (\%) \\
\hline Age mean \pm SD $(32.4 \pm 12.9$ years $)<20$ years & $15(3.0)$ \\
\hline $20-29$ years & $17(34.0)$ \\
\hline $30-39$ years & $12(24.0)$ \\
\hline$\geq 40$ years & $35(70.0)$ \\
\hline \multicolumn{1}{|c|}{ Occupation } & $9(18.0)$ \\
\hline Housewife & $6(12.0)$ \\
\hline Student & \\
\hline Employed & Marital Status \\
\hline Married & $41(82.0)$ \\
\hline
\end{tabular}




\section{Journal of Gynecology and Women's Health}

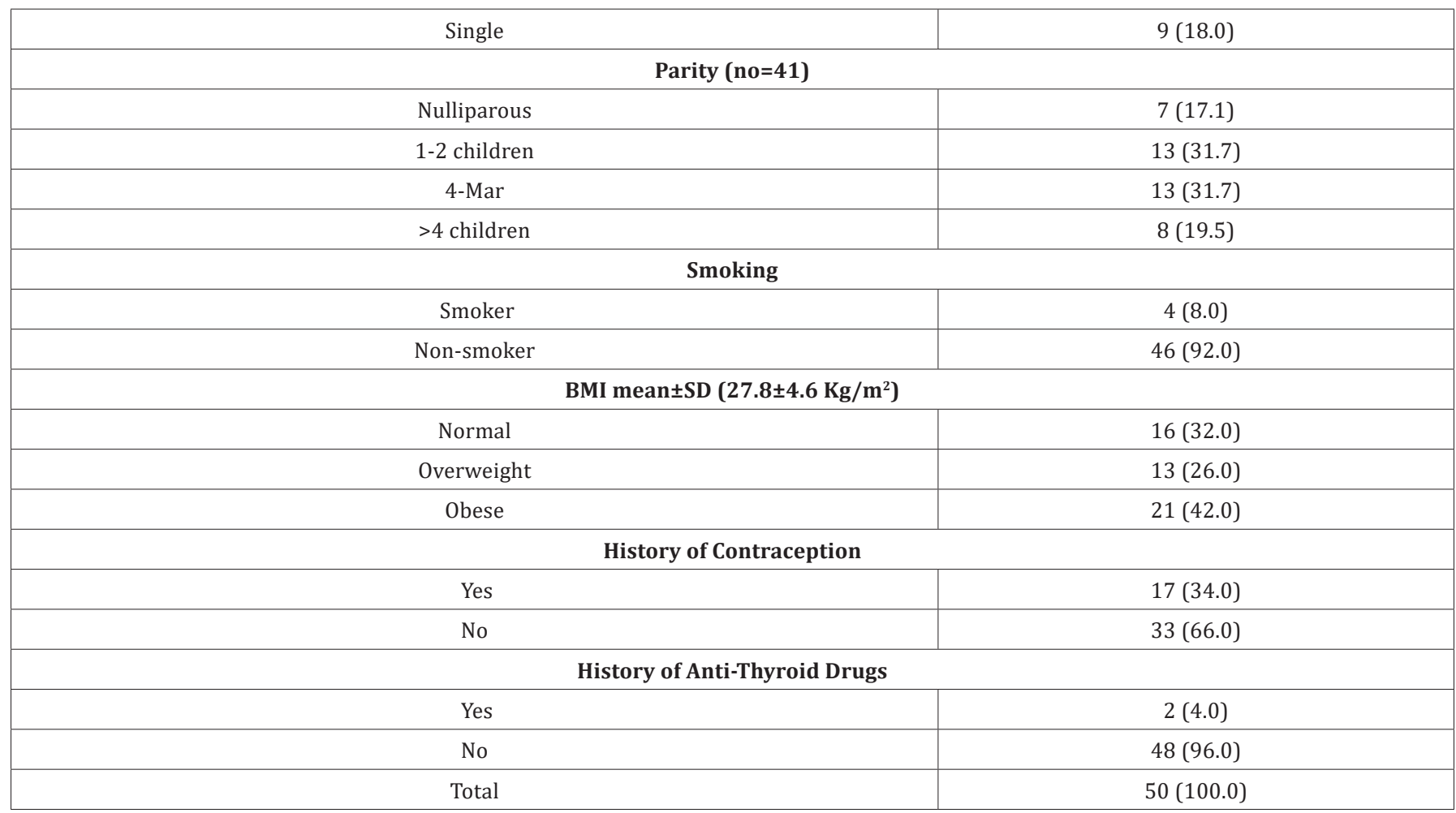

Regarding menstrual cycle of women with AUB, cycle regularity was irregular among $64 \%$ of them and 5 (10\%) women had normal menstrual cycle, furthermore $21(42 \%)$ women had menorrhagia, 23(46\%) women had oligomenorrhea and only $1(2 \%)$ woman had polymenorrhea. The post coital bleeding was detected among 2(4\%) women and intermenstrual bleeding was detected in 5(10\%) women. Among those only 3(6\%) had Pap smear which were normal (of note there is no cervical screening provided in our country. Mean TSH of women with AUB was $2.7 \mu \mathrm{U} / \mathrm{ml} ; 6 \%$ of women with AUB had low TSH level and $24 \%$ of them had high TSH level. Mean T3 of women with AUB was 1.6 $\mathrm{pmol} / \mathrm{L}$; only one (2\%) woman with AUB had low T3 level. Mean T4 of women with AUB was $85.2 \mathrm{pmol} / \mathrm{L} ; 10 \%$ of women had low T4. The majority of women with AUB were euthyroid (72\%), however $22 \%$ of women with AUB had hypothyroidism and $6 \%$ of them had hyperthyroidism (Table 2).

Table 2: Menstrual disturbances and thyroid function of women with AUB $(n=50)$.

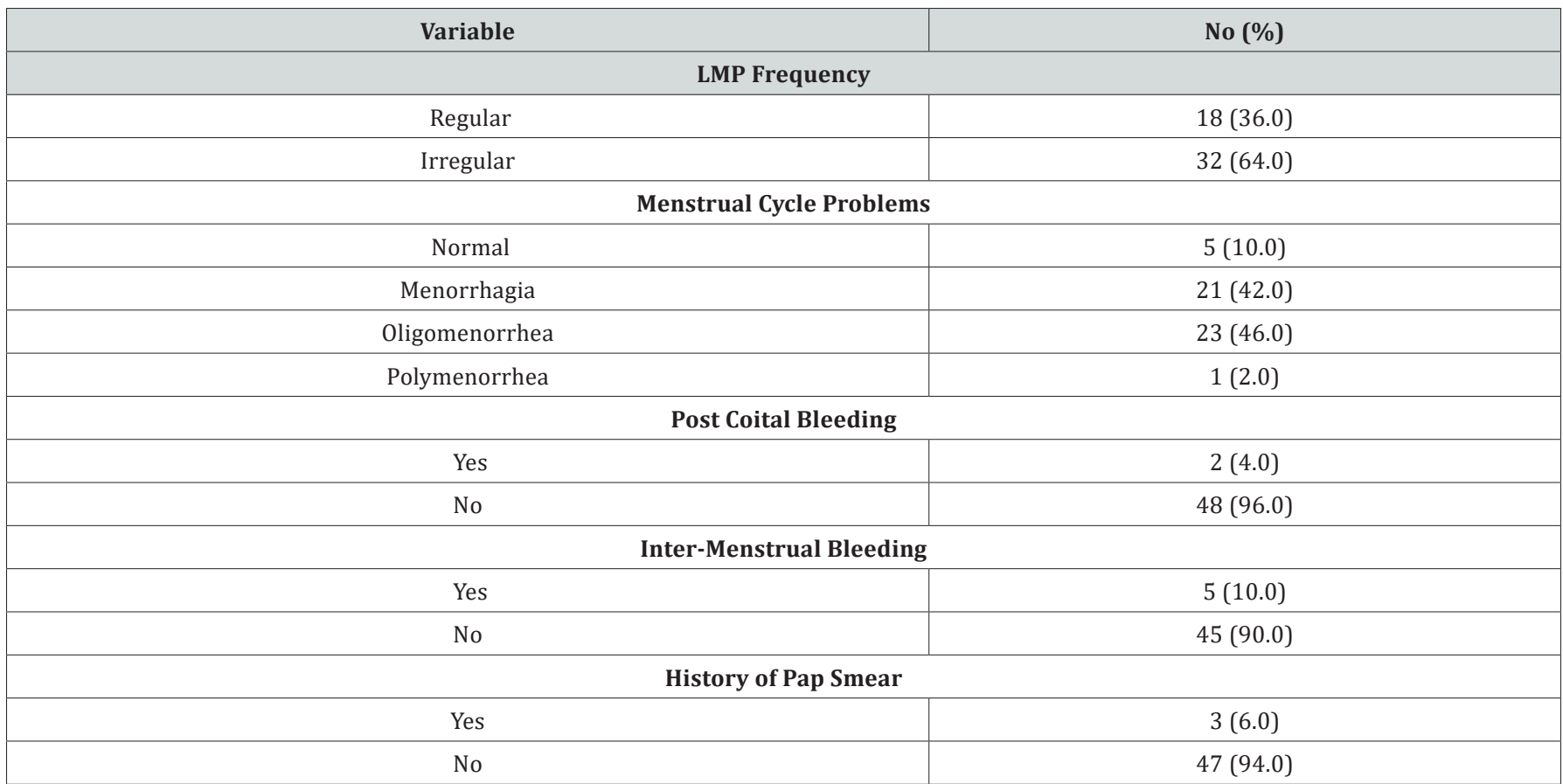




\section{Journal of Gynecology and Women's Health}

\begin{tabular}{|c|c|}
\hline \multicolumn{2}{|c|}{ TS Hmean \pm SD $(2.7 \pm 2.2 \mu \mathrm{U} / \mathrm{ml})$} \\
\hline Normal & $35(70.0)$ \\
\hline Low & $3(6.0)$ \\
\hline High & $12(24.0)$ \\
\hline \multicolumn{2}{|c|}{$\mathrm{T} 3 \mathrm{mean} \pm \mathrm{SD}(1.6 \pm 0.6 \mathrm{pmol} / \mathrm{L})$} \\
\hline Normal & $49(98.0)$ \\
\hline Low & $1(2.0)$ \\
\hline \multicolumn{2}{|c|}{$\mathrm{T} 4 \mathrm{mean} \pm \mathrm{SD}(85.2 \pm 30.2 \mathrm{pmol} / \mathrm{L})$} \\
\hline Normal & $45(90.0)$ \\
\hline Low & $5(10.0)$ \\
\hline \multicolumn{2}{|c|}{ Thyroid Function } \\
\hline Euthyroid & $36(72.0)$ \\
\hline Hypothyroidism & $11(22.0)$ \\
\hline Hyperthyroidism & $3(6.0)$ \\
\hline Total & $50(100.0)$ \\
\hline
\end{tabular}

Comparing AUB women with control women with no AUB revealed no significant differences regarding age $(p=0.9)$, occupation $(p=0.9)$, marital status $(p=0.2)$, parity $(p=0.3)$, BMI $(\mathrm{p}=0.3)$, smoking $(\mathrm{p}=0.1)$ and euthyroid women wile on thyroid replacement therapy $(\mathrm{p}=1.0)$. There was a significant association between positive contraception history and women with AUB $(\mathrm{p}=0.001)$. Table $3 \& 4$ showed a highly significant difference between AUB women and controls was observed regarding LMP frequency and meonorrhagia \& oligomenorrhea $(p<0.001)$. No significant differences were observed between AUB women and controls regarding post coital bleeding $(\mathrm{p}=0.1)$ and history of
Pap smear $(\mathrm{p}=0.07)$. There was a significant association between intermenstrual bleeding and women with AUB ( $\mathrm{p}=0.02)$. The common interesting findings in our study were the significant association between high TSH level and women with AUB $(\mathrm{p}=0.002)$. No significant differences were observed between AUB women and controls regarding T3 level $(\mathrm{p}=0.5)$. Women with AUB were significantly associated with low $\mathrm{T} 4$ level $(\mathrm{p}=0.04)$; $10 \%$ of AUB women had low T4 level. A significant association was observed between women with AUB and hypothyroidism ( $p=0.003$ ); $22 \%$ of AUB women had hypothyroidism while $2 \%$ of controls had hypothyroidism (Table 4).

Table 3: Distribution of women baseline characteristics according to study groups $(n=100)$.

\begin{tabular}{|c|c|c|c|}
\hline Variable & AUB No. (\%) & Control No. (\%) & $P$ value \\
\hline Age & & & $0.9^{*}$ \\
\hline$<20$ years & $6(12.0)$ & $8(16.0)$ & \\
\hline 20-29 years & $15(30.0)$ & $13(26.0)$ & \\
\hline 30-39 years & $17(34.0)$ & $16(32.0)$ & \\
\hline$\geq 40$ years & $12(24.0)$ & $13(26.0)$ & \\
\hline Occupation & & & $0.9^{*}$ \\
\hline Housewife & $35(70.0)$ & $33(66.0)$ & \\
\hline Student & $9(18.0)$ & $10(20.0)$ & \\
\hline Employed & $6(12.0)$ & $7(14.0)$ & \\
\hline Marital Status & & & $0.2 *$ \\
\hline Married & $41(82.0)$ & $36(72.0)$ & \\
\hline Single & $9(18.0)$ & $14(28.0)$ & \\
\hline Parity & & & $0.3^{*}$ \\
\hline Nulliparous & 7 (17.1) & $0(-)$ & \\
\hline 1-2 children & $13(31.7)$ & $5(55.6)$ & \\
\hline $3-4$ & $13(31.7)$ & $2(22.2)$ & \\
\hline$>4$ children & 8 (19.5) & $2(22.2)$ & \\
\hline BMI & & & $0.3^{*}$ \\
\hline Normal & $16(32.0)$ & $18(36.0)$ & \\
\hline Overweight & $13(26.0)$ & $18(36.0)$ & \\
\hline
\end{tabular}




\section{Journal of Gynecology and Women's Health}

\begin{tabular}{|c|c|c|c|}
\hline Obese & $21(42.0)$ & $14(28.0)$ & \\
\hline Smoking & & & $0.1^{*}$ \\
\hline Smoker & $4(8.0)$ & $1(2.0)$ & \\
\hline Non-smoker & $46(92.0)$ & $49(98.0)$ & \\
\hline History of Contraception & & & $0.001^{* *}$ \\
\hline Yes & $17(34.0)$ & $4(8.0)$ & \\
\hline No & $33(66.0)$ & $46(92.0)$ & \\
\hline History of Anti-Thyroid Drugs & & & $1.0^{*}$ \\
\hline Yes & $2(4.0)$ & $2(4.0)$ & \\
\hline No & $48(96.0)$ & $48(96.0)$ & \\
\hline
\end{tabular}

Table 4: Distribution of women menstrual disturbances and thyroid function according to study groups $(n=100)$.

\begin{tabular}{|c|c|c|c|}
\hline Variable & AUB No. (\%) & Control No. (\%) & P Value \\
\hline LMP Frequency & & & $<0.001^{* *}$ \\
\hline Regular & $18(36.0)$ & $48(96.0)$ & \\
\hline Irregular & $32(64.0)$ & $2(4.0)$ & \\
\hline Menstrual Cycle Problems & & & $<0.001^{* *}$ \\
\hline Normal & $5(10.0)$ & $49(98.0)$ & \\
\hline Menorrhagia & $21(42.0)$ & $1(2.0)$ & \\
\hline Oligomenorrhea & $23(46.0)$ & $0(-)$ & \\
\hline Polymenorrhea & $1(2.0)$ & $0(-)$ & \\
\hline Post Coital Bleeding & & & $0.1^{*}$ \\
\hline Yes & $2(4.0)$ & $0(-)$ & \\
\hline No & $48(96.0)$ & $50(100.0)$ & \\
\hline Inter-Menstrual Bleeding & & & $0.02^{* *}$ \\
\hline Yes & $5(10.0)$ & $0(-)$ & \\
\hline No & $45(90.0)$ & $50(100.0)$ & \\
\hline History of Pap Smear & & & $0.07 *$ \\
\hline Yes & $3(6.0)$ & $0(-)$ & \\
\hline No & $47(94.0)$ & $50(100.0)$ & \\
\hline TSH & & & $0.002^{* *}$ \\
\hline Normal & $35(70.0)$ & $48(96.0)$ & \\
\hline Low & $3(6.0)$ & $1(2.0)$ & \\
\hline High & $12(24.0)$ & $1(2.0)$ & \\
\hline T3 & & & $0.5^{*}$ \\
\hline Normal & $49(98.0)$ & $48(96.0)$ & \\
\hline Low & $1(2.0)$ & $2(4.0)$ & \\
\hline $\mathrm{T} 4$ & & & $0.04^{* *}$ \\
\hline Normal & $45(90.0)$ & $49(94.0)$ & \\
\hline Low & $5(10.0)$ & $0(-)$ & \\
\hline High & $0(-)$ & $1(2.0)$ & \\
\hline Thyroid Function & & & $0.003^{* *}$ \\
\hline Euthyroid & $36(72.0)$ & $48(96.0)$ & \\
\hline Hypothyroidism & $11(22.0)$ & $1(2.0)$ & \\
\hline Hyperthyroidism & $3(6.0)$ & $1(2.0)$ & \\
\hline
\end{tabular}




\section{Discussion}

Abnormal uterine bleeding is accompanied by low quality of life attributed to treatment efforts of bleeding and outcomes of high blood loss like fatigability and anemia [15]. The endocrine disturbances play a major role in pathogenesis of abnormal uterine bleeding [16]. In our study the most common AUB was oligomenorrhea(23\%) followed by menorrhagia (21\%) followed by inter menstrual bleeding (5\%). These findings are consistent with reports of Fraser et al. [17] study in USA which included the oligomenorrhea and menorrhagia within the definition of abnormal uterine bleeding. Deshmukh et al. [16] and Byna et al 9 reported the menorrhagia as the most common type of AUB. The intermenstrual bleeding in our study was significantly associated with AUB women $(\mathrm{p}=0.02)$. Similarly, Mohan et al. [18] documented that intermenstrual bleeding is a frequent presentation of abnormal uterine bleeding. Our study revealed predominance of contraception history among women with AUB ( $p=0.001)$. Previous American study [19] documented that hormonal contraception is the major cause of AUB among women in reproductive age period.

This study revealed a significantly higher level of thyroid stimulating hormone among women with AUB in comparison to controls $(\mathrm{p}=0.002)$. This finding coincides with results of Attia et al. [20] study in Egypt which found a significant difference in TSH between women with AUB and controls. Our study also showed a significant association between low $\mathrm{T} 4$ hormone level and women with AUB ( $\mathrm{p}=0.04)$. This finding is in agreement with results of large cohort study carried out in USA by Kang et al. [21] which stated that low T4 hormone level was significantly related to AUB. Abnormal thyroid hormones levels contributed to disturbances in ovulatory hormones and predisposing to irregular bleeding [22].

Our study showed that hypothyroidism constitutes $22 \%$ of women with AUB and hyperthyroidism did present in $6 \%$ of them. These findings are higher than results of previous Iraqi study conducted by Al-Hakeim [23] which found that among women with menstrual disturbances, the hypothyroidism present in $16.1 \%$ of them and hyperthyroidism was present in $3.4 \%$ of them. This difference in thyroid dysfunction between two studies might be due to geographical variation and high prevalence of thyroid disorders in Kurdistan [14]. Our study finding regarding hypothyroidism is also higher than that of Ajmani study in India [5] of 14\% among women with menstrual disorders. Current study showed a significant association between women with AUB and hypothyroidism ( $p=0.003)$. This finding is similar to results of many previous studies $[24,25]$. Whitaker et al. [26] documented the hypothyroidism is one of the common diseases that must be assessed among women with abnormal uterine bleeding. The prevalence of hypothyroidism is high in Iraq country [27] and specifically in Kurdistan region [28]. The mechanism by which the hypothyroidism can affect the menstrual cycle is not fully understood. However, some authors attributed this relationship to irregular or no ovulation that decreases the luteinizing hormone and elevating the estrogen leading to menstrual bleeding [16].

\section{Conclusion}

The thyroid dysfunction is common cause of abnormal uterine bleeding among reproductive age women. The oligomenorrhea and menorrhagia are the prevalent bleeding types. Thyroid hormones assessment should be taken in consideration in assessment of women with abnormal uterine bleeding.

\section{References}

1. Mahajan N, Aggarwal M, Bagga A (2012) Health issues of menopausal women in North India. J Midlife Health 3(2): 84-87.

2. Talukdar B, Mahela S (2016) Abnormal uterine bleeding in perimenopausal women: Correlation with sonographic findings and histopathological examination of hysterectomy specimens. J Midlife Health 7(2): 73-77.

3. Munro MG, Critchley HO, Fraser IS (2012) The FIGO systems for nomenclature and classification of causes of abnormal uterine bleeding in the reproductive years: who needs them? Am J Obstet Gynecol 207(4): 259-265.

4. Hassan FF (2017) The Frequency of Histopathological Patterns in Endometriam Obtained from a Sample of Iraqi Women with Abnormal Uterine Bleeding. Karbala Journal of Medicine 10(3): 3846-3856.

5. Ajmani NS, Sarbhai V, Yadav N, Paul M, Ahmad A, et al. (2016) Role of Thyroid Dysfunction in Patients with Menstrual Disorders in Tertiary Care Center of Walled City of Delhi. J Obstet Gynaecol India 66(2): 115119.

6. Ramahi I, Faisal A, AbdulHassan I, Barausrux X (2010) Study of thyroid hormones among female Iraqi thyroid disorders. The $2^{\text {nd }}$ Annual International Conference of Northeast Pharmacy Research, pp. 57-59.

7. Pahwa S, Gupta S, Kaur J (2013) Thyroid Dysfunction in Dysfunctional Uterine Bleeding. Journal of Advance Researches in Medical Sciences 5(1): 78-83.

8. Bhavani N, Sathineedi A, GiriA, Chippa S, Reddy VSP, et al. (2015) A study of correlation between abnormal uterine bleeding and thyroid dysfunction. Journal of Recent Trends in Science and Technology 14(1): 131-135.

9. Byna P, Siddula S, Kolli S, Shaik MV (2015) Thyroid abnormality in perimenopausal women with abnormal uterine bleeding. Int J Res Med Sci 3(11): 3250-3253.

10. Mansourian AR (2013) Female reproductive physiology adversely manipulated by thyroid disorders: A review of literature. Pak J Biol Sci 16(3): 112-120.

11. Sharma N, Sharma A (2012) Thyroid profile in menstrual disorders. JK Science 14(1): 14-17.

12. Al-Naffii KO, Nasseralah CABM HAA, Al-Hillali KA, Ali AFM (2008) Hypothyroidism in adults early clinical presentation in relation to age. Karbala Journal of Medicine 2(3): 352-356.

13. Verma SK, Pal A, Jaswal S (2017) A study of thyroid dysfunction in dysfunctional uterine bleeding. Int J Reprod Contracept Obstet Gynecol 6(5): 2035-2039.

14. Al-Bustany DA (2011) Clinical study of cases with hyperthyroidism in Erbil Governorate, Kurdistan Region-Iraq. Zanco Journal of Medical Sciences 15(1): 6-12.

15. Liu Z, Doan QV, Blumenthal P, Dubois RW (2007) A systematic review evaluating health related quality of life, work impairment and health 
care costs and its utilization in abnormal uterine bleeding. Value Health 10(3): 183-194.

16. Deshmukh PY, Boricha BG, Pandey A (2015) The association of thyroid disorders with abnormal uterine bleeding. Int J

Reprod Contracept Obstet Gynecol 4(3): 701-708.

17. Fraser IS, Critchley HO, Broder M, Munro MG (2011) The FIGO recommendations on terminologies and definitions for normal and abnormal uterine bleeding. Semin Reprod Med 29(5): 383-390.

18. Mohan S, Page LM, Higham JM (2007) Diagnosis of abnormal uterine bleeding. Best Pract Res Clin Obstet Gynaecol 21(6): 891-903.

19. Schrager S (2002) Abnormal uterine bleeding associated with hormonal contraception. Am Fam Physician 65(10): 2073-2080.

20. Attia AH, Youssef D, Hassan N, El-Meligui M, Kamal M, et al. (2007) Subclinical hyperthyroidism as a potential factor for dysfunctional uterine bleeding. Gynecol Endocrinol 23(2): 65-68.

21. Kang JH, Kueck AS, Stevens R, Curhan G, Vivo DI, et al. (2013) A Large Cohort Study of Hypothyroidism and Hyperthyroidism in Relation to Gynecologic Cancers. Obstet Gynecol Int 2013: 743721.

22. Muttappallymyalil J, Sreedharan J, Al Biate MAS, Mummigatti K, Shantakumari N, et al. (2014) Prolactin level in women with Abnormal Uterine Bleeding visiting Department of Obstetrics and Gynecology in a University teaching hospital in Ajman, UAE. Proceedings of the $6^{\text {th }}$ Annual Scientific Meeting of Gulf Medical University 2014: 92-98.

23. Al-Hakeim HK, Jassim WE, Ali IA (2010) Prevalence of Endocrine Disorders among Iraqi Women with Menstrual Disturbances. Karbala J Med 3(3): 889-896.

24. Marimuthu K, Loganathan M (2017) Influence of thyroid gland in women with abnormal uterine bleeding in reproductive age group. Int J Reprod Contracept Obstet Gynecol 6(6): 2222-2225.

25. Kanwar G, Shekhawat M, Sharma N, Hada Y, Kabra R, et al. (2015) Hypothyroidism- A Risk Factor for Menstrual Disorders among Nulliparous Females. IOSR Journal of Dental and Medical Sciences 14(12): 78-81.

26. Whitaker L, Critchley HOD (2016) Abnormal uterine bleeding. Best Practice \& Research Clinical Obstetrics \& Gynaecology 34: 54-65.

27. Al Shahrani1 AS, El-Metwally A, Al-Surimi K, Salih SB, Saleh Y, et al. (2016) The epidemiology of thyroid diseases in the Arab world: A systematic review. J Public Health Epidemiol 8(2): 17-26.

28. Jawzali JI (2017) Regional Differences of Drinking Water Iodine and Its Association with Thyroid Disorder and Serum Iodine. Medical Journal of Babylon 14(1): 198-208.

\section{Your next submission with Juniper Publishers will reach you the below assets}

- Quality Editorial service

- Swift Peer Review

- Reprints availability

- E-prints Service

- Manuscript Podcast for convenient understanding

- Global attainment for your research

- Manuscript accessibility in different formats

( Pdf, E-pub, Full Text, Audio)

- Unceasing customer service

Track the below URL for one-step submission https://juniperpublishers.com/online-submission.php 